Magdalena Pawlak

Uniwersytet Łódzki

\title{
Wartościowanie sztuki dla dzieci w przygotowaniu zawodowym nauczycieli edukacji wczesnoszkolnej
}

Pozycja nauczyciela edukacji wczesnoszkolnej, z uwagi na funkcję wprowadzania dzieci w świat wartości kultury, jest przedmiotem wnikliwej uwagi i oceny pedagogów. I tak Zbyszko Melosik i Tomasz Szkudlarek uważają, że:

Nauczyciel szczególnie we wczesnej edukacji jest Wszechmocnym Kreatorem Rzeczywistości, w której dzieci żyją. To on wyznacza granice tego, co jest a co nie jest dozwolone, on „ostatecznie” stwierdza, co jest dobre, a co złe, co jest prawdą, a co kłamstwem. Jego wiedza i przekonania na temat rzeczywistości, sensu życia, systemu wartości stają się dla uczniów Prawdziwe, choćby z racji formalnego autorytetu nauczyciela i jego prerogatyw w zakresie oceniania osiągnięć, a de facto „stanu tożsamości:” uczniów. Większość z nauczycieli z upodobaniem wchodzi w rolę „nosiciela" Prawdy i Wiedzy. Ich własna tożsamość (wraz z jej meandrami: wartościami, poczuciami, marzeniami) jest praktykowana i urzeczywistniana w codziennym życiu szkoły. Ich małe, najmniejsze, niekiedy nieuświadomione (często pełne kompleksów) teorie na temat rzeczywistości stają się dla uczniów obowiązujące. Zmuszeni są oni żyć w świecie, którego horyzonty wyznaczone są przez horyzonty i dobrą wolę nauczyciela. W odróżnieniu od filozofa, który spisuje swoje teorie w tomy i błaga los o uzyskanie przywileju i szczęścia „kształtowania dusz" (lub choćby o czytelnika), nauczyciel teorie swoje praktykuje od zaraz, natychmiast, niekiedy bez cienia refleksji ${ }^{1}$.

Z powyższych słów wynika zarówno wysoka sprawczość jak i odpowiedzialność nauczycieli za edukację kulturalną dzieci. Została tu także wyrażona obawa o subiektywizm i schematyzm wprowadzanych kategorii wartościowania kultury, bliskich tylko nauczycielowi. Podobne opinie co do odpowiedzialności nauczyciela za wczesną edukację kulturalną dzieci wyrażali pedagodzy związani z edukacją estetyczną, szczególnie dotyczącą

\footnotetext{
${ }^{1}$ Z. Melosik, T. Szkudlarek, Kultura, tożsamość i edukacja - migotanie znaczeń, Kraków 2010, s. 18.
} 
literatury. Bogusław Żurakowski² uważa, że nauczyciel, który sam nie potrafi dokonać poprawnej interpretacji utworu współczesnego pisarza, czyli odnaleźć w utworze wartości estetycznych i artystycznych, nie będzie też w stanie zaprezentować poprawnego sądu estetycznego. Tym samym z powodu braku odpowiedniego przygotowania nie będzie potrafił ukierunkować doświadczenia estetycznego, literackiego dziecka. Zdaniem autora, mniej ważne jest, czy interpretacja utworu będzie miała charakter aktywnej działalności, np. zabawowej, recytatorskiej czy dramowej, bowiem każda interpretacja wymaga zrozumienia i wyrażenia sensu utworu. Żurakowski uważa, że sam adres czytelniczy oraz fakt istnienia w literaturze obszarów aktywnych aksjologicznie, jakby oczekujących na odpowiedź dziecka, nie wystarcza, aby wartości te spełniły się; dziecko potrzebuje, aby dorosły pomógł mu w odbiorze literatury. Pomoc ta jednak musi spełnić kilka warunków.

Jednym z nich jest otwartość dorosłego nauczyciela na różne systemy kulturowe i zdolność aktywnego i kreatywnego przeżywania i rozumienia treści poznawanych kultur. Jak zauważyła Maria Tyszkowa, powierzchowne i wąskie wdrażanie do określonego kręgu kultury symbolicznej może:

obok efektów pozytywnych powodować skutki negatywne w rozwoju indywidualnym człowieka, blokując pewne jego sfery, np. rozwój myślenia operacyjnego w pewnych obszarach, utrzymywanie sfer irracjonalności w wyniku sztywnego zaakceptowania pewnych wartości kulturowych, zahamowanie ekspresji osobowości itp. ${ }^{3}$

Najczęściej nauczyciel podporządkowuje literaturę celom pedagogicznym, ocenia ją z punktu widzenia postępowania dziecka oraz z punktu widzenia wzbogacenia wiedzy o świecie. Generalnie rzecz biorąc, w ocenie Żurakowskiego literatura piękna podporządkowana zostaje celom rozwijania mowy, myślenia i odczuwania dziecka. Same zaś wartości literackie są wykorzystywane do zdobywania umiejętności operowania słowem i wywoływania odpowiednich reakcji emocjonalnych.

Drugi warunek skutecznego przekazu wartości estetycznych stanowi poznanie świata przeżyć estetycznych dziecka. Charakterystykę przeżyć estetycznych okresu dzieciństwa zaprezentowała Maria Gołaszewska ${ }^{4}$. Jest

${ }^{2}$ B. Żurakowski, Wartości estetyczne w literaturze, [w:] M. Tyszkowa, B. Żurakowski (red.), Wartości w świecie dziecka i sztuki dla dziecka, Warszawa-Poznań 1984, s. 226.

${ }^{3}$ M. Tyszkowa, Kultura symboliczna, wartości i rozwój jednostki, [w:] M. Tyszkowa, B. Żurakowski (red.), Wartości w świecie dziecka..., s. 43-44.

${ }^{4}$ M. Gołaszewska, Szkic o dziecięcej naiwności, [w:] M. Tyszkowa, B. Żurakowski (red.), Wartości w świecie dziecka..., s. 197. 
to jedna z bardziej użytecznych i nadal aktualnych teorii wyjaśniających poziom recepcji wartości estetycznych przez dziecko. Gołaszewska uznała, iż takie wartości, jak piękno, wzniosłość i tragizm są niedostępne dziecku, ponieważ oprócz wrażliwości wymagają pewnej sprawności intelektualnej, określonego poziomu kultury ogólnej i umiejętności dostrzegania metafizycznej strony rzeczywistości.

Jak się wydaje, dziecko nie odczuwa, że świat jest „przeciwko niemu” (albo co najmniej obojętny), nie odczuwa bezpośrednich zagrożeń, przed którymi chronione jest przez dorosłych, dlatego co przedstawione bywa w sztuce jako groźne, tragiczne, dla niego ma wymiar: „straszenia dla zabawy”.

Komizm dzieci przeżywają na zasadzie silnych kontrastów zewnętrznych. Nie mają dystansu krytycznego i często nie rozumieją całości sytuacji. Natomiast tę wartość estetyczną, która dzieciom jest dostępna, określa cytowana autorka mianem naiwności. Warto przypomnieć cztery podstawowe cechy naiwności jako kategorii estetycznej, wymienione przez Gołaszewską. Są to:

1) postawa wobec świata jako rzeczywistości bliskiej i życzliwej,

2) naturalność - w znaczeniu pierwotności, w tym sensie, że naiwność ujmuje struktury naturalne, rzeczywistości realnej, natomiast struktury, które kreuje ona, budowane są na śladach struktur naturalnych,

3) brak elementu doskonałości warsztatowej wywodzącej się z kształcenia czy treningu,

4) świeżość czyli nieuprzedzone spojrzenie na rzeczywistość ${ }^{6}$.

Cenne są również wskazania Gołaszewskiej co do praktyki wychowawczej, a więc obowiązujące nauczyciela.

Po pierwsze, warunkiem zrozumienia i zaakceptowania wrażliwości dziecięcej w sferze artystycznej i estetycznej jest umiejętność zachowania w sobie czegoś z naiwności, co wyraża się poprzez docenianie naturalności, szczerości, autentyczności, optymistycznej wiary w bliskość i życzliwość świata.

Po drugie, naiwności nie należy traktować jako właściwości przynależnej jedynie do niższego stadium rozwoju, lecz jako jedną z wartości cechujących świat człowieka, zwłaszcza świat dziecka.

\footnotetext{
${ }^{5}$ Ibidem, s. 197.

${ }^{6}$ Ibidem, s. 198-199.
} 
Po trzecie, kierując rozwojem dziecka, należy starać się, by jak najdłużej zachowało ono swoją naiwność. Jest to bowiem stan najbardziej naturalny dla niego, zapewniający mu zdrowie psychiczne.

Wreszcie czwarta uwaga, bardzo istotna dla przedstawianych rozważań, to zalecenia aby w analizie wytworów dziecka oraz jego postawy estetycznej uwzględniać w znacznej mierze kategorię naiwności. Wobec wcześniej cytowanych opinii o zagrażających nauczycielom schematyczności i jednokierunkowości w wartościowaniu kultury, a tym samym sztuki dla dziecka, propozycja M. Gołaszewskiej może stanowić skuteczną przeciwwagę wobec zgłaszanych zastrzeżeń, bowiem daje nauczycielom obiektywną kategorię opisywania i wartościowana sztuki dla dziecka z punktu widzenia jego możliwości przeżywania estetycznego.

Taka kategoria wyjaśniająca i oceniająca sztukę dla dziecka jest tym bardziej zasadna, że w rozwoju wrażliwości estetycznej u dzieci wyróżniono dwa czynniki: wrażliwość sensoryczną i wrażliwość na struktury artystycz$n^{7}$. Pierwszy rodzaj wrażliwości jest wynikiem uwarunkowań fizjologiczno-organicznych przeżycia estetycznego, co oznacza, że może być rozwijana, ale tylko do pewnego stopnia. Drugi rodzaj, wrażliwość na struktury artystyczne, rozwija się w okresie dzieciństwa, początkowo samorzutnie, a następnie ulegając wpływom środowiska kulturowego. Co ważne, ten rodzaj wrażliwości może i powinien stanowić przedmiot zabiegów wychowawczych. Jest to bowiem wrażliwość preferencyjna na określone jakości, wyodrębniane jako kategorie estetyczne. U dzieci podczas odbierania różnych wrażeń ze świata następuje samorzutne uwrażliwienie na określony rodzaj bodźców wzrokowych czy dźwiękowych. W ten sposób ujawnia się, zdaniem Gołaszewskiej, preferencja dotycząca określonego rodzaju wrażeń estetycznych, co stanowi podstawę kształtowania się cechy osobniczej.

Obok preferencyjnego, biologicznie uwarunkowanego rozwoju wrażliwości na wartości estetyczne, działalność wychowawcza stanowi drugi czynnik warunkujący prawidłowy rozwój estetyczny dziecka. Przy czym, na co zwracała uwagę wielokrotnie M. Tyszkowa, wczesne doświadczenia sensoryczne uwarunkowane kulturowo odgrywają rolę pierwowzorów formujących przebieg procesów percepcyjnych i ich złożoność kulturalnąa ${ }^{8}$.

Pierwsze struktury percepcyjne stają się wewnętrznymi schematami percepcji danej jednostki. Ukształtowane pod wpływem kultury nawyki

\footnotetext{
${ }^{7}$ M. Gołaszewska, Kultura estetyczna, Warszawa 1979, s. 10-11.

${ }^{8}$ M. Tyszkowa, Kultura symboliczna..., s. 36 .
} 
percepcyjne co prawda zwiększają wrażliwość na pewne typy stymulacji sensorycznej, np. na pewien typ muzyki, ale utrudniają zarazem odbiór i satysfakcję w kontakcie z innymi jej rodzajami, odmiennymi od rodzimej i znanej konwencji kulturowej. Przejęcie i przeżycie różnorodnych kodów symbolicznych pozwala człowiekowi na poszukiwanie różnych możliwości ich zastosowania, a także służy do sprawdzania różnych kombinacji w obrębie danego systemu symbolicznego. Odnosi się to także do zabaw dziecięcych. W przypadku osób dorosłych umożliwia to przyjęcie postawy otwartości wobec dzieł zastanych i współtworzonych ${ }^{9}$.

Współcześnie akceptacja różnorodności przekazów kulturowych, a co za tym idzie, wielość kodów symbolicznych, nabierają jeszcze większego znaczenia. Cytowane powyżej opinie zostały sformułowane w latach osiemdziesiątych, obecnie postulat otwartości to wręcz warunek konieczny bycia w kulturze.

W stosunku do literatury dziecięcej wyróżniono charakterystyczne dla tej dziedziny wartości estetyczne. Uznajmy je za tzw. propozycję klasyczną, stanowi ją zespół cech nazwanych przez B. Żurakowskiego paidialnością ${ }^{10}$. Na paidialność składają się mityczność, baśniowość i zabawowość.

Szczególnie ważną formą literatury dziecięcej są baśnie; „zawarty w nich przekaz świata fikcji od pokoleń służył kształtowaniu kulturowych wzorców osobowościowych, przygotowywał do zrozumienia świata realnego i radzenia sobie z wewnętrznymi problemami człowieka" ${ }^{11}$. Anna Mazur podkreśla znaczenie języka używanego w tradycyjnych baśniach, który jest pełen barwnych obrazowych określeń odnoszących się do cech wizualnych i cech charakteru postaci ${ }^{12}$. Jako przykład „zubożenia literackiego” podaje disneyowskiego Kubusia Puchatka, gdzie specyficzny język pełen wyrafinowanego humoru zastąpiono prostym komunikatem, a oryginalne ryciny - krzykliwymi rysunkami. To zubożenie odnosi się również do współczesnego języka, którym opisywane są zjawiska kultury. Tendencja do upraszczania przekazów werbalnych we współczesnym świecie ma wpływ na wszystkie dziedziny rzeczywistości, dotyczy zatem także trudności w znalezieniu adekwatnych pojęć dla zjawisk wizualnych ${ }^{13}$.

\footnotetext{
${ }^{9}$ Ibidem, s. 36-37.

${ }^{10}$ B. Żurakowski, Wartości estetyczne w literaturze..., s. 221.

${ }^{11}$ B. Bettelheim, Cudowne i pożyteczne. O znaczeniu i wartościowaniu baśni, t. 1, 1985, [za:] A. Mazur, Rozwijanie wrażliwości percepcyjnej jako podstawowy element przygotowania do odbioru sztuki, [w:] B. Paprocka (red.), Wybrane problemy..., Lublin 2013, s. 65.

${ }^{12}$ A. Mazur, Rozwijanie wrażliwości percepcyjnej..., s. 65.

${ }^{13}$ Ibidem, s. 65.
} 
Anna Mazur przypomniała także interesujące badania Henryka Zygnera, w których wykazano wpływ czytania bajek pełnych pojęć określających barwy, wielokrotnie powtarzanych w toku narracji, na efektywność zapamiętywania i identyfikowania barw przez dzieci pięcioletnie ${ }^{14}$. Jest to przykład na to, że słowo pomaga wizualizować cechę przedmiotu, jaką jest barwa, a więc wspiera zasób wrażliwości estetycznej dziecka.

Proces percepcji dzieła to proces poznawczy. Według Tomasza Marciniaka, składa się na niego wiele operacji psychicznych, jak: widzenie, rozumienie czy interesujące $w$ tych rozważaniach wartościowanie dzieła ${ }^{15}$. Stanowi ono rodzaj dialogu między artystą i odbiorcą. Rezultat zależy od formy dzieła, postawy estetycznej, kultury plastycznej czy zainteresowań odbiorcy. Dzieło sztuki zawiera wartości wizualne, wartości ideowe, denotatywne i wartości estetyczno-artystyczne, jak: forma, kompozycja, środki wyrazu, konwencja. Wartościowanie sztuki jest zatem procesem, który można kształtować przez całe życie.

Wobec różnorodności formy i treści przekazów kulturowych skierowanych do dzieci, wymagających od nauczycieli otwartości na kody artystyczne, interesujące jest, jak nauczyciele edukacji wczesnoszkolnej wartościują sztukę dla dzieci.

W tym celu przeprowadzono badania w grupie przyszłych nauczycieli edukacji wczesnoszkolnej, tj. studentów II roku pedagogiki przedszkolnej i wczesnoszkolnej. Badania przeprowadzone zostały w styczniu 2012 roku na Wydziale Nauk o Wychowaniu Uniwersytetu Łódzkiego. Studentom polecono przygotowanie, do wyboru, recenzji pedagogiczno-estetycznej książki lub filmu dla dzieci. Do oceny literatury przyjęto następujące kategorie:

1) wątek przygodowy - aktywność bohatera,

2) elementy fantastyczno-magiczne i ich funkcje,

3) kod moralny,

4) eksterioryzacja doświadczeń i przeżyć dziecka, odbiorcy - projekcja uczuć,

5) interioryzacja doświadczeń i przeżyć bohatera - identyfikacja dziecka $\mathrm{z}$ bohaterem,

6) ocena wartości wychowawczej,

\footnotetext{
${ }^{14}$ Ibidem, s. 65.

${ }^{15}$ T. Marciniak, Model edukacji plastycznej (próba integracji), 1986, [za:] J. Florczykiewicz, Terapia przez sztuke jako metoda wspierająca oddziaływanie resocjalizacyjne, [w:] W. Limont, K. Nielek-Zawadzka (red.), Dylematy edukacji artystycznej, Kraków 2006, s. 546.
} 
7) ocena wartości estetycznej, plastycznej (ilustracje).

Przy ocenie filmu należało wziąć pod uwagę następujące kryteria:

1) tytuł i twórcy,

2) treść - główny wątek,

3) adekwatność treści do wieku dziecka,

4) ogólny klimat emocjonalny filmu (ewentualna obecność scen agresji, przemocy),

5) ocena estetyki filmu: dźwięki, kolorystyka, obraz, język,

6) ocena wychowawcza: propagowane modele postępowania, wzory zachowań wobec osób i sytuacji trudnych,

7) otwartość i wieloznaczność utworu.

W odpowiedzi uzyskano 47 recenzji na 72 uczestników badań. Reszta studentów wolała test wiadomości z przedmiotu niż samodzielne formułowanie oceny.

Dominującą dziedziną ocenianej sztuki był film - 27 recenzji, baśń recenzowało 19 studentów.

Wśród wybranych filmów większość stanowiły filmy animowane (Shrek, Król Lew) i mieszane - animacja i aktorzy (Alicja w Krainie Czarów, Garfield), mniejszość stanowiło kino typowo aktorskie (4 wybory: Tajemniczy ogród, Jumanji). Wybierano filmy popularne, w stylu disneyowskim (11 osób), który znany był studentom $z$ dzieciństwa. Wśród propozycji połowę stanowiły filmy z dzieciństwa studentów, a połowę produkcje filmowe $\mathrm{z}$ ostatnich lat.

Wśród książek wszystkie pozycje były studentom znane z dzieciństwa. Dominowały klasyczne i dobrze znane baśnie: Czerwony Kapturek, Brzydkie kaczątko. Spośród autorów najczęściej wybierano braci Grimm i Andersena. Należy zaznaczyć, że 1/3 badanych w ogóle nie podała autora baśni.

W recenzjach większość opisu zajmowała zazwyczaj poprawna ocena wartości moralnej i wychowawczej. Natomiast elementy analizy dotyczące oceny estetycznej nie zawierały dużo treści. W recenzjach skupiano się zazwyczaj na krótkim opisie walorów estetycznych. W pojedynczych przypadkach podjęto próbę samodzielnego oceniania utworu pod kątem estetycznym.

Nikt nie zrealizował punktu dotyczącego otwartości i wieloznaczności dzieła filmowego.

Wartość estetyczną baśni najczęściej oceniano pod względem adekwatności ilustracji do przedstawianej treści. W pięciu przypadkach pojawiła się 
informacja o adekwatności kolorystycznej do treści emocjonalnych baśni poprzez użycie ciemnych i jasnych barw. Najczęściej formułowano oceny typu: „książka cieszy oko małego czytelnika”, „przyjemne dla oka”, niewnoszące żadnych konkretnych informacji. W przypadku baśni dostarczono dwie próby samodzielnej oceny wartości estetycznej. Opis dotyczył również walorów językowych utworów. Najważniejsze dla studentów okazało się kryterium jasności przekazu językowego dla dzieci. Pojawiły się też sformułowania o występujących środkach stylistycznych: epitetach i rymach.

W ocenie filmów, w których użyto grafiki komputerowej, studentów interesował stopień podobieństwa postaci animowanych do postaci rzeczywistych. Pozytywnie oceniano triki filmowe pozwalające na połączenie grafiki z rzeczywistością.

W odniesieniu do muzyki filmowej stosowano określenia: „łatwo wpadające w ucho piosenki”, „muzyka nie pozwala się nudzić” itp.

W ośmiu pracach w ogóle nie nawiązano do zagadnień estetyki filmowej. Częściej studenci szukali błędów i niedociągnięć, które ich zdaniem obniżałyby wartość estetyczną filmu i w rezultacie formułowali ogólne opinie typu: „nie da się zauważyć jakiś niedociągnięć w przejściach od jednej sceny do drugiej".

W pracach zaobserwowano brak spójności w ocenianiu elementów dzieła filmowego. Studenci zwracali uwagę na jeden, ewentualnie dwa elementy strukturalne filmu, takie jak: język i dialogi, montaż, muzyka, grafika i animacja, rzadziej kolorystyka. Na ich podstawie formułowali całościową ocenę filmu. Pojedyncze osoby zwróciły także uwagę na dobór kostiumów, dopasowanie wyglądu zewnętrznego do charakteru postaci.

W jednej z prac dotyczących filmu Shrek opis był stosunkowo obszerny. Podkreślono wartości dialogów, jak komizm, ironia, dowcip. Zwrócono też uwagę na aspekty pomijane u innych: „Montażem zajął się Sim Evan-Jones. Został zrobiony naprawdę profesjonalnie [...] Niezwykle soczysta kolorystyka obrazu, sposób animacji składają się na niezwykłe dzieło. Przywiązanie do detali i realizmu daje wspaniały efekt”.

Za kolejną wyróżniającą się pracę uznać trzeba nieco poetycką recenzję filmu Piotruś i Wilk:

Wahania nastrojów oraz silne przeciążenia systemu wartości podkreśla znakomicie skomponowana w 1936 roku muzyka. Z jednej strony wydaje się być przezroczystą, spełniającą raczej funkcje towarzyszące niż narracyjne melodią, z drugiej subtelnie wpływa na nasz nastrój i podświadomie kieruje naszą percepcję w kierunku najistotniejszych wydarzeń. 
Autorka zwróciła również uwagę na montaż oraz na ogólny obraz złożony ze scenografii, oświetlenia oraz animacji.

Studentom brakuje odwagi w odkrywaniu znaczeń estetycznych we własnych doświadczeniach i przeżyciach związanych ze sztuką. W analizowanych pracach widać omawiane w literaturze problemy w posługiwaniu się językiem sztuki. Przyczyna może tkwić w błędach w sposobie wychowania rodzinnego i szkolnego, a także w niedoskonałości systemu kształcenia nauczycieli.

$\mathrm{Na}$ podobne przyczyny uproszczenia przekazów werbalnych odnoszących się do sztuki wskazała Lidia Suchanek ${ }^{16}$, według której pokolenie dzisiejszych studentów, w tym studentów pedagogiki, ma problemy w interpretacji zjawisk kultury. Autorka, dokonując analizy prac plastycznych studentów studiów o profilu pedagogicznym, zauważa brak występowania w nich metafory. Lidia Suchanek postrzega pracę plastyczną jako komunikat o sposobie postrzegania świata przez autora. W analizowanych przez nią pracach dominuje schematyczny, powtarzalny układ, podobny do form stosowanych przez dzieci. W pracach dominują formy z otaczającej rzeczywistości i realistyczne motywy. Problemem dla studentów okazuje się stworzenie abstrakcyjnej formy pozbawionej realnego odniesienia. Pomimo zrozumienia terminu metafory, studenci nie potrafią sami „metaforyzować” 17 . Autorka dodaje: „kiedy wyobraźnia tkwi w konwenansie schematu, zanika zdolność uważnego obserwowania, brakuje chęci do twórczych inicjatyw, gdy nic twórczego nie dzieje się w miejscu transgresji i transcendowania"18.

Istotne jest zatem rozwijanie u przyszłych nauczycieli umiejętności posługiwania się bogatym językiem sztuki, rozumienia jej przekazów, w tym metafor, wartościowania jej, ale także umiejętności tworzenia własnych wypowiedzi artystycznych, rozwijania własnej twórczości. Tylko wtedy będą oni mogli być odpowiednimi przewodnikami wprowadzającymi dziecko w świat sztuki i kultury.

Ostatnie decyzje ministerialne, zobowiązujące studentów edukacji wczesnoszkolnej do ukończenia jedynie licencjatu, spowodowały widoczne odchodzenie od kontynuowania studiów w tej specjalizacji na drugim stopniu. W poszukiwaniu mobilności zawodowej, wymuszonej rynkiem pracy, studenci wybierają inne, dość różnorodne studia magisterskie. Pro-

\footnotetext{
${ }^{16}$ L. Suchanek, Problemy komunikacji językiem sztuki w kontekście edukacji, [w:] K. Pankowska (red.), Sztuka i wychowanie. Wspótczesne problemy edukacji estetycznej, Warszawa 2010, s. 117.

${ }^{17}$ Ibidem, s. 118-119.

${ }^{18}$ Ibidem, s. 118.
} 
gram studiów magisterskich jest w większym stopniu ukierunkowany na samodzielność poznawczą i badawczą studentów. Ułatwia to im refleksyjność i świadomą autokreację, czego zabrakło w analizowanych recenzjach, w ostrożnych i schematycznie sformułowanych opiniach i ocenach estetycznej wartości sztuki dla dziecka.

\section{Bibliografia}

Florczykiewicz J., Terapia przez sztuke jako metoda wspierajaca oddziatywanie resocjalizacyjne, [w:] W. Limont, K. Nielek-Zawadzka (red.), Dylematy edukacji artystycznej, Kraków 2006.

Gołaszewska M., Kultura estetyczna, Warszawa 1979.

Mazur A., Rozwijanie wrażliwości percepcyjnej jako podstawowy element przygotowania do odbioru sztuki, [w:] B. Paprocka (red.), Wybrane problemy edukacji artystycznej dzieci i młodzieży, Lublin 2013.

Melosik Z., Szkudlarek T., Kultura, tożsamość i edukacja - migotanie znaczeń, Kraków 2010.

Suchanek L., Problemy komunikacji językiem sztuki w kontekście edukacji, [w:] K. Pankowska (red.), Sztuka i wychowanie. Wspótczesne problemy edukacji estetycznej, Warszawa 2010.

Tyszkowa M., Żurakowski B. (red.), Wartości w świecie dziecka i sztuki dla dziecka, Warszawa-Poznań 1984. 